\title{
Circulation profile of respiratory viruses in symptomatic and asymptomatic children from Midwest Brazil
}

\author{
Italo Araujo Castro ${ }^{1}$ (D) - Lusmaia Damaceno Camargo Costa ${ }^{2}$. Anniely Carvalho Rebouças Oliveira ${ }^{1} \cdot$ Menira Souza $^{1}$. \\ Divina das Dôres de Paula Cardoso ${ }^{1}$. Paulo Augusto Moreira Camargos ${ }^{3} \cdot$ Paulo Sergio Sucasas Costa $^{2}$. \\ Fabiola Souza Fiaccadori ${ }^{1}$
}

Received: 27 November 2019 / Accepted: 21 August 2020 / Published online: 29 August 2020

(C) Sociedade Brasileira de Microbiologia 2020

\begin{abstract}
Acute respiratory infection (ARI) is a major cause of morbidity and mortality worldwide. Most of these infections are caused by viruses. Infections pose as important triggers of acute episodes of chronic respiratory diseases (CRD). This study sought to evaluate the frequency and circulation profile of respiratory viruses among ARI symptomatic patients and completely asymptomatic children in Midwest Brazil. The study enrolled symptomatic children with and without ARI symptoms. During 1 year, 225 nasal respiratory samples were obtained from patients aged 4-14 years old. The samples were screened by multiplex nestedPCR for 16 common respiratory viruses. From 225 samples, 42 had at least one virus detected. Samples from four different patients had multiple viruses detected. The viral detection rate in symptomatic (20.1\%) and asymptomatic patients (14.8\%) showed no significant difference. The most frequent viruses detected were rhinovirus (28.6\%), FLUA (11.9\%), adenovirus (11.9\%), human bocavirus (HBoV) (11.9\%), and respiratory syncytial virus (RSV) antigenic group A (9.5\%). Monthly detection rate was higher during the rainy season. RSVs were detected during the months with higher rainfall indexes and higher air humidity, while FLU and HBoV were detected during the winter months. The obtained results reinforce the importance of viral pathogens in pediatric population, emphasizing similar viral occurrence in symptomatic and asymptomatic children.
\end{abstract}

Keywords Respiratory viruses $\cdot$ Asymptomatic children $\cdot$ Circulation profile $\cdot$ Multiplex PCR

\section{Introduction}

Acute respiratory infections (ARI) are important causes of illness worldwide, with significant burden to public health.

Responsible Editor: Mauricio Nogueira.

Electronic supplementary material The online version of this article (https://doi.org/10.1007/s42770-020-00368-0) contains supplementary material, which is available to authorized users.

Italo Araujo Castro

italo.a.castro@usp.br

1 Instituto de Patologia Tropical e Saúde Pública, Departamento de Microbiologia, Imunologia, Parasitologia e Patologia, Laboratório de Virologia Humana, Universidade Federal de Goiás, Goiânia, GO, Brazil

2 Faculdade de Medicina, Departamento de Pediatria, Universidade Federal de Goiás, Goiânia, GO, Brazil

3 Hospital Universitário, Unidade de Pediatria e Pneumologia, Universidade Federal de Minas Gerais, Belo Horizonte, MG, Brazil
ARIs are frequent in all age groups and the leading cause of morbidity and mortality in young infants, especially in developing countries [1]. Among respiratory pathogens, viruses account for a great percentage of infections and respiratory disease in humans [2]. According to the Brazilian Ministry of Health, 15 thousand cases of viral ARIs were notified in 2016, with more than 2500 fatal cases [3]. The variety of viruses that infect the respiratory tract is considerable, and the overlapping symptoms make the clinical diagnosis a hard task. Thus, specific diagnosis relies almost entirely on laboratory investigation.

The role of viruses triggering other respiratory diseases, including wheezing and asthma exacerbations, remains unclear for some agents such as human metapneumovirus (hMPV) and bocavirus (HBoV) $[4,5]$, whereas for other viral pathogens this association is more well defined. Human Rhinoviruses (HRV) account for 35\% of infection-related asthma episodes, followed by respiratory syncytial virus (RSV) [6] and influenza viruses (FLU) [7]. There has been an increase in reports of detection of respiratory viruses in 
asymptomatic individuals, which may be due to the high sensitivity of molecular methods. Alternatively, this may indicate the presence of persistent viral infections and prolonged shedding, which has already been suggested for specific anatomic sites [8].

Worsening of respiratory symptoms remains a challenging health issue, with relevant economic and social burden, which reinforces the need for a better understanding of the diverse triggering factors, especially respiratory viral infections. In order to evaluate the relationship with presence of acute respiratory symptoms, we performed a molecular investigation of 16 respiratory viruses in symptomatic and asymptomatic pediatric population, analyzing the viral detection rate among different patient groups and the circulation profile during 1 year.

\section{Materials and methods}

\section{Study design and population}

The study group included children aged 4-14 years attended in five reference pediatric healthcare centers in Goiânia, Goiás, Brazil, from September 2012 to August 2013. Two main groups were determined: symptomatic and asymptomatic children. The symptomatic group included children with ARI and without asthma, defined as more than two previous wheezing episodes with dyspnea requiring therapy with bronchodilator. ARI symptoms were fever, coryza, sore throat, and cough in the past $48 \mathrm{~h}$, including exacerbated episodes. At the same healthcare centers, children with no ARI symptoms in the past 30 days were recruited to compose the asymptomatic group. Patients with underlying conditions such as cystic fibrosis, bronchiectasis, diabetes, immunodeficiency from any cause, kidney failure, chronic encephalopathy, and metabolic disorders were excluded from the study. The study was approved by the Clinical Research Ethics Committee (HC/UFG Protocol 175/2011) of the Federal University of Goiás. Nasopharyngeal aspirates (NPAs) were collected from patients following Brazilian Ministry of Health recommendations, after parents or guardians signed the informed consent form. Clinical and epidemiological questionnaires were filled out by the attending physicians. Nasal swabs were collected when aspirates were not possible to be obtained. Samples were transported in minimum essential medium (MEM), kept at $4{ }^{\circ} \mathrm{C}$, and processed within $4 \mathrm{~h}$.

\section{Methodology}

Nasopharyngeal aspirates and/or nasal swab samples were initially clarified by centrifugation at $3000 \mathrm{rpm}, 10 \mathrm{~min}$. Total viral DNA and RNA were subsequently extracted by QIAmp Cador pathogen Mini Kit (QIAGEN, Germany) from sample supernatants, following manufacturer's instructions. From total nucleic acid, $1 \mathrm{ng}$ was converted to cDNA by reverse transcription using M-MLV enzyme (Invitrogen, Carlsbad, CA, USA) and random hexamers (PdN6; Invitrogen). Cycling conditions for cDNA synthesis were $65{ }^{\circ} \mathrm{C}, 5 \mathrm{~min}$, followed by $25^{\circ} \mathrm{C}, 10 \mathrm{~min} ; 37^{\circ} \mathrm{C}, 50 \mathrm{~min}$; and a final inactivation step at $70{ }^{\circ} \mathrm{C}$ for $15 \mathrm{~min}$, according to the manufacturer's guidelines.

Multiplex nested PCR screening was performed for 16 common respiratory viral pathogens, divided in three different PCR protocols using primers previously described [9-13]. The first protocol comprised specific primer pairs to detect FLU A, B, and C and RSV A and B [13]. GoTaq Colorless Master Mix PCR (Promega, Madison, WI, USA) was used in both first and second amplifications, with $0.16 \mathrm{mM}$ of each primer. Then, $4 \mu \mathrm{L}$ of the cDNA was added at the final volume of $25 \mu \mathrm{L}$. PCR cycling conditions were a first step of $94{ }^{\circ} \mathrm{C}$ for 2 min followed by 45 cycles of $94{ }^{\circ} \mathrm{C}, 30 \mathrm{~s} ; 50^{\circ} \mathrm{C}$, $2 \mathrm{~min} ; 68^{\circ} \mathrm{C}, 1 \mathrm{~min}$; and a final step of $68^{\circ} \mathrm{C}, 10 \mathrm{~min}$. Nested PCR was carried out using $4 \mu \mathrm{L}$ of the PCR product. Cycling conditions were initially a $94{ }^{\circ} \mathrm{C}, 30 \mathrm{~s}$ step, followed by $35 \mathrm{cy}-$ cles of $94{ }^{\circ} \mathrm{C}, 30 \mathrm{~s} ; 55^{\circ} \mathrm{C}, 1 \mathrm{~min} ; 72^{\circ} \mathrm{C}, 30 \mathrm{~s}$; and a final step of $72{ }^{\circ} \mathrm{C}, 10 \mathrm{~min}$. The second protocol comprised specific primer pairs to detect PIV 1-4, Human Coronavirus (HCoV) 229E and OC43, HRV, and Enteroviruses (hEV) [10]. First and second reactions were conducted as described above. PCR Cycling conditions were $94{ }^{\circ} \mathrm{C}, 3 \mathrm{~min} ; 45$ cycles of $94{ }^{\circ} \mathrm{C}, 30 \mathrm{~s} ; 55^{\circ} \mathrm{C}, 90 \mathrm{~s} ; 72{ }^{\circ} \mathrm{C}, 1 \mathrm{~min}$; and a final step of $72^{\circ} \mathrm{C}, 10 \mathrm{~min}$. Nested PCR was conducted using $2 \mu \mathrm{L}$ of the PCR amplicon, and cycling conditions were the same as described for the first Nested PCR protocol.

Finally, the third protocol included primers specific for Adenovirus (HAdV) [9], HBoV [12], and hMPV (A and B) [11]. Both first and second amplification protocols were conducted as mentioned previously, although $0.2 \mathrm{mM}$ of each primer had been used instead of 0.16 . Cycling conditions were $94{ }^{\circ} \mathrm{C}, 3 \mathrm{~min} ; 40$ cycles of $94{ }^{\circ} \mathrm{C}, 30 \mathrm{~s} ; 53{ }^{\circ} \mathrm{C}, 1 \mathrm{~min} ; 72^{\circ} \mathrm{C}$, $40 \mathrm{~s}$; and a final step of $72^{\circ} \mathrm{C}, 10 \mathrm{~min}$, for the first reaction. Nested PCR used $2 \mu \mathrm{L}$ from the first round amplicon. Cycling conditions were $94{ }^{\circ} \mathrm{C}, 3 \mathrm{~min}$ followed by 30 cycles of $94^{\circ} \mathrm{C}$, $30 \mathrm{~s} ; 55^{\circ} \mathrm{C}, 1 \mathrm{~min} ; 72{ }^{\circ} \mathrm{C}, 40 \mathrm{~s}$; and a final step of $72{ }^{\circ} \mathrm{C}$, $10 \mathrm{~min}$. Internal control plasmid DNA pGEM-T Easy Vector (Promega, Madison, WI, USA) was included into each sample lysate following manufacturer's guidelines from the extraction kit. M13 primers were used to amplify the internal control following the first Multiplex PCR protocol described above to monitor sample extraction process and the presence of inhibitors for the downstream application. Positive clinical samples for all respiratory viruses tested were kindly provided by Prof. Dr. Wyller Mello and were used as positive controls. Negative control (MiliQ sterile water) was also included in each PCR run. Positive samples were confirmed by monoplex PCR using virus-specific primers. Additionally, for each of 
the three PCR mixes described previously, up to three representative samples were randomly chosen for confirmatory genomic Sanger sequencing, using the same PCR primers. Consensus sequences were generated and analyzed with BLAST tool to confirm the similarity with other sequences available in GenBank (Supplementary Fig. 1). All steps were performed in separated rooms, including mix preparation, reverse transcription and complementary DNA synthesis, first and second PCR amplifications, genomic sequencing, and electrophoresis, in order to prevent contamination.

\section{Meteorological data}

Data regarding environmental factors such as monthly rainfall $(\mathrm{mm})$, average minimum and maximum temperature $\left({ }^{\circ} \mathrm{C}\right)$. and relative air humidity (\%) were acquired from Brazilian National Institute of Meteorology (INMET) for the 20122013 period.

\section{Statistical analysis}

Comparison of viral detection rates between the patient groups as well as other variables were analyzed by $\chi^{2}$ or Fisher's exact tests. All analyses were performed using IBM SPSS v.20 (SPSS Inc.; Chicago, IL, USA), Epi Info v.7 (Centers for Disease Control and Prevention; Atlanta, GA, USA) and GraphPad Prism v.7 (GraphPad Software, Inc.) software, with the significance level set to 0.05 .

\section{Results}

From September 2012 to August 2013, 225 children were recruited and had respiratory samples collected (193 NPAs and 32 nasal swabs). Of those, $72.9 \%$ (164) were symptomatic children and $27.1 \%$ (61) asymptomatic children. The mean age of children in the symptomatic group was $7.09 \pm 2.55$ and asymptomatic children $8.3 \pm 2.9$ (Table 1 ).

At least one respiratory virus was detected in $20.1 \%$ of symptomatic children and $14.8 \%$ of the asymptomatic patient group $(p=0.18)$. Considering all patients, no significant differences were detected between age and sex regarding viral detection rate (Table 1). Nevertheless, detection of respiratory viruses was higher in children younger than 7 years old in the asymptomatic group ( $p=0.045$, CI 95\%) (Fig. 1). Regardless of the presence of symptoms, HRV was the most frequently detected virus $(28.6 \%)$, followed by FLUA (11.9\%), HAdV (11.9\%), HBoV (11.9\%), PIVs (11.9\%), and RSVA (9.5\%). Also, OC43 (4.76\%), FLUC (2.4\%), RSVB (2.4\%), and 229E $(2.4 \%)$ were detected in reduced frequencies. In four patients (three symptomatic and one asymptomatic), two respiratory viruses were detected, three of them had HRV associated with a second virus, PIV2, PIV3, or FLUB, and one had both HEV and $\mathrm{HBoV}$ detected.

Different virus profiles were observed in the two patient groups, and HRV was the most frequent agent in both groups. Influenza (A and B) and RSV (A and B) were detected exclusively in symptomatic patients, and those had the highest diversity of distinct viruses (Fig. 2).

Respiratory viral pathogens were detected throughout the entire study period (Fig. 3a) and viral detection rates correlated positively with relative humidity and rainfall $(r>0)$ (Fig. $3 \mathrm{~b}$ ), being higher during the rainy season, period of the year comprising months with high relative air humidity (RAH), and high amount of rainfall (Table $1 ; p=0.009$, CI 95\%).

Due to the low number of samples positive for individual viruses and the relatively short study period, seasonal circulation profiles for specific agents could not be well defined. However, clear seasonal trends were observed for three viruses. RSVA and B peaked between January and March 2013, trimester marked by high RAH and rainfall; FLU viruses were more frequent between April and June 2013, during the fall of $\mathrm{RAH}$ after a long rainy season; and $\mathrm{HBoV}$ was detected from March to June 2013, peaking in April 2013. HRV, which was the most frequently detected virus, showed no clear seasonal pattern and was detected all year round (Fig. 4).

\section{Discussion}

To the best of our knowledge, this is the first study based on molecular detection of respiratory viruses in children, including asymptomatic individuals, in Midwest Brazil. We have successfully screened 225 children for 16 common respiratory viruses using an in-house multiplex nested-PCR protocol during a study period of 1 year.

The virus detection rate was higher among symptomatic children (20.1\%). Recent investigations from distinct countries have shown viral detection rates of $25.7-80 \%$ in respiratory samples obtained from children with acute respiratory infection symptoms [14-16]. Positivity rates from previous Brazilian studies ranged from 31 to $85 \%$ [17-19]. These rates are relatively higher than those found in this study. However, some aspects must be considered before comparing the present data with the data from the studies mentioned above. It is important to emphasize that the type of viral screening protocols used, the sampling method itself, patients' age group, and local geographic and meteorological features may lead to discrepancies in detection rates and viral circulation profiles. When the populations' age intervals are considered, while in this study children were aged from four to 14 years old, in the other studies, most of the children were aged up to 4 years old, and therefore, higher viral detection rates were found in younger children $[15,18,20]$. This trend was also noticed in the age subgroups, with higher positivity rate among younger children 
Table 1 Population characteristics and positive samples distribution

\begin{tabular}{llll}
\hline Characteristics & Number $(\%)$ & Virus detection & \\
\cline { 3 - 3 } & & At least one virus detected/Total (\%) & $P$ value \\
\hline Age (year) & & & \\
$\leq 7$ & $122(54.2)$ & $27 / 122(22.1)$ & 0.07 \\
$8-14$ & $103(45.8)$ & $15 / 103(14.5)$ & 0.9 \\
Sex & & & \\
Male & $134(59.6)$ & $25 / 134(18.7)$ & 0.18 \\
Female & $91(40.4)$ & $17 / 91(18.7)$ & \\
Group & $164(72,9)$ & $33 / 164(20.1)$ & $0.009 *$ \\
Symptomatic children & $61(27.1)$ & $9 / 61(14.8)$ & \\
Asymptomatic children & & & \\
Year season & $172(76.4)$ & $26 / 172(15.12)$ & \\
Dry period & $53(23.6)$ & $16 / 53(30.19)$ & \\
Rainy period & & & \\
\hline
\end{tabular}

*Statistically significant test
( $\leq 7$ years), but with no statistical significance $(p>0.05)$ (Table 1).

The detection of viruses in asymptomatic children was a noteworthy finding. Several studies have described significant detection of respiratory viruses in asymptomatic children, and authors attributed this fact with increasing use of molecular assays, lower pathogenicity of some respiratory viruses, and lower virus clearance among infants $[21,22]$. These results should be considered with caution, once viral nucleic acids may be detected due to prolonged shedding and do not imply necessarily in asymptomatic infection [21]. Our findings also suggest that the presence of viral nucleic acid seems to be more frequent in younger children, which is in agreement with studies conducted in the Netherlands and USA in asymptomatic pediatric individuals $[23,24]$.

Seasonal profiles of respiratory viral infections are well defined for temperate climate regions of the globe. However, for tropical regions, especially in humid climates this profile remains unclear (36-39). According to data from INMET and IBGE, Goiânia has a tropical wet-and-dry climate. Relative air

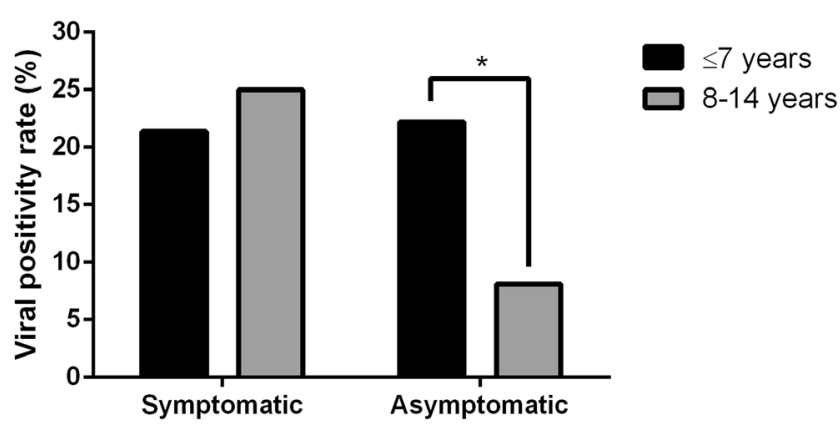

Fig. 1 Detection rate of respiratory viruses in symptomatic and asymptomatic patients according to age (years). Frequencies of different age groups were compared using paired Fisher's test. * $p=0.045$, CI $95 \%$ humidity (RAH) is low for the most part of the year with an average temperature of $24^{\circ} \mathrm{C}$. It has two well-defined seasons, a wet season comprising the months of October to April and a dry season, from May to September. During September 2012 and 2013, average temperature recorded was $25^{\circ} \mathrm{C}$, average RAH of $57.7 \%$, and average rainfall of $108.1 \mathrm{~mm}$.

Under these environmental conditions, we observed a direct relationship between the viral detection rates and RAH, with most of the cases occurring between October 2012 and March 2013 ( $p=0.009,95 \%$ CI), months marked by high levels of RAH and amount of rainfall. Data from other tropical countries, such as Hong Kong, Malaysia, and Honduras, showed similar seasonal profiles of respiratory viruses [25-27].

Brazil is the fifth largest country of the world, with more than 8 million $\mathrm{km}^{2}$ of area, with broadly variable climate subtypes in several regions. Concurrent with the climatic diversity observed in the country, seasonal data from respiratory viruses are also variable. A study conducted in Ceará state, northeast

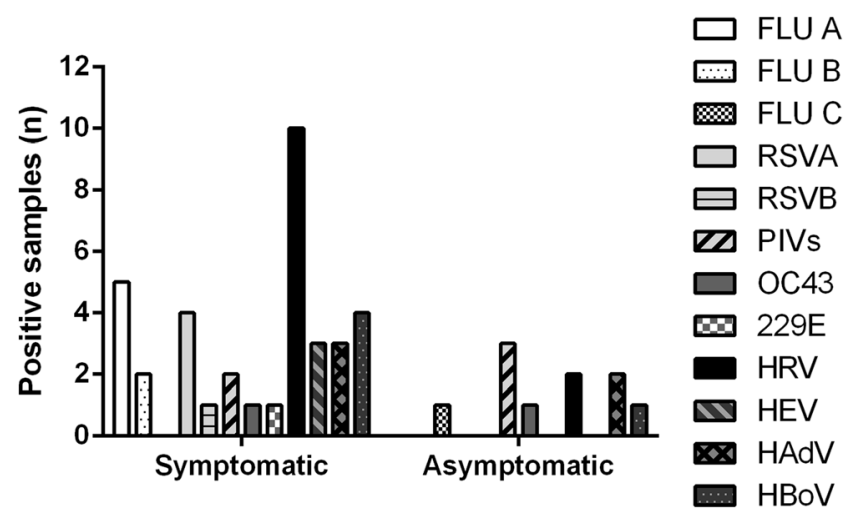

Fig. 2 Diversity of respiratory viruses detected among different study groups 
Fig. 3 a Distribution of viral detection rates during 12 months of study. Positivity rates (percentages) were plotted against rainfall and relative air humidity (RAH). Left $y$ axis: rainfall (mm). Right $y$ axis: percentages. b Association between viral detection rates and meteorological parameters was analyzed using Pearson correlations. Both " $p$ " and " $r$ " values are indicated in the graph for each variable analyzed

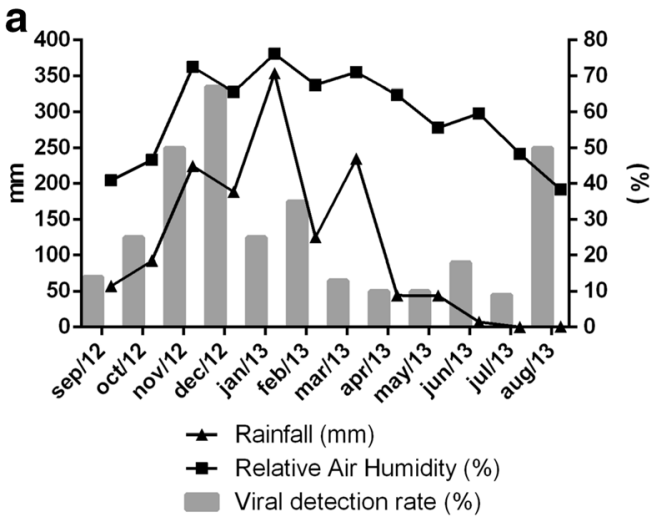

region, reported statistical significant correlation between peaks of FLU detection and the rainy season [28]. Nevertheless, recent studies from South and Southeast regions have suggested an inverse relationship between RAH and respiratory viral detection rates $[29,30]$.

It was difficult to define a general circulation profile comprising all 16 viruses screened, considering those viruses come from distinct families and may have many different biological features. Based on that we attempted to analyze individual profiles and even so, only three viruses showed clear seasonal patterns. RSV peaked at the wet season months January to March 2013, in accordance with previous studies that evaluated the circulation profile of $\operatorname{RSV}[25,26]$. In a recent study conducted in Vietnam, Anders and cols have detected RSV episodes only at months with high amount of rainfall, among newborn children followed until the first year of age [31]. FLU viruses peaked mostly at the months where RAH was declining due to the concomitant decline of rainfall. Another previous study has also described similar results [28]. These findings were also corroborated by Brazilian Ministry of Health epidemiologic survey for the Midwest region in 2013 [32].

Human bocaviruses were detected between March and June 2013, months marked by temperature, RAH, and rainfall dropping. Previous studies have reported the predominant

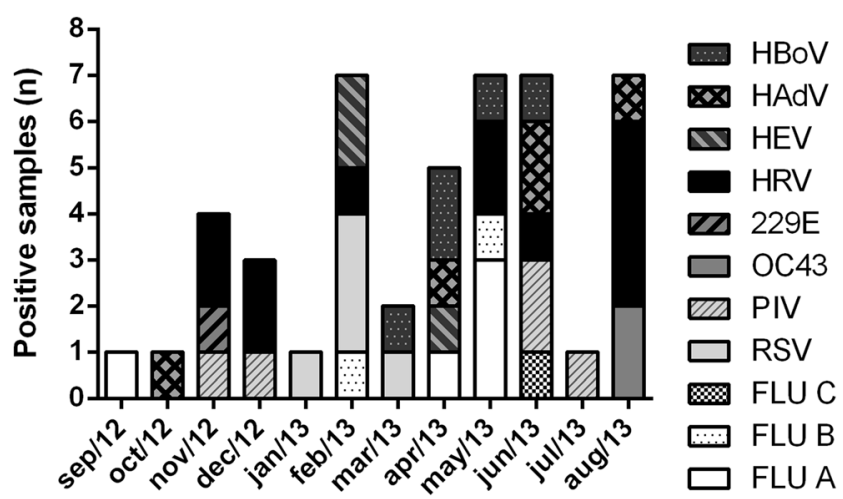

Fig. 4 Circulation profile of respiratory viruses according to the monthly number of positive samples circulation of $\mathrm{HBoV}$ during winter [30]. Nonetheless, recent data suggested the predominance of $\mathrm{HBoV}$ infections during the humid and rainy months $[33,34]$. HRV, the most prevalent viruses detected, could not have a well-defined circulation profile, once it has been detected throughout the year, which is in accordance with study conducted by Anders et al., 2015 [31].

The limitations of the study may have impaired statistical analysis. The number of asymptomatic patients was lower than the number of symptomatic group, due to difficulties of recruiting patients without respiratory symptoms. For sampling, other authors [35] also reported this challenge and in addition to the relatively low number of patients recruited, it may have reduced the statistical power.

This study is the first study on respiratory virus molecular detection to be conducted in the central region of Brazil. The obtained data may aid in filling the knowledge gaps about seasonality and circulation of respiratory viruses. The detection of respiratory viruses in all groups, especially in asymptomatic children, reinforces the importance of these pathogens in pediatric population. Asymptomatic infections may affect not only the diagnostic and surveillance of individual viruses but also in the maintenance of these agents in the population. Data provided background information on comprehension of respiratory viruses impact among respiratory symptoms in children, although further investigations are needed to fully understand this relationship. Finally, we also need studies accessing whether detection of viral nucleic acids in asymptomatic individuals really implies in a productive and persistent infection.

Acknowledgments We would like to thank Dr. Wyller Mello from Laboratório de Vírus Respiratórios, Evandro Chagas Institute, who gently provided the positive controls used in this study.

Funding This study was supported by the Goiás State Research Support Foundation (FAPEG), process number 201310267000273. 


\section{Compliance with ethical standards}

Conflict of interests The authors declare that they have no conflict of interest.

\section{References}

1. Niederman MS, Krilov LR (2013) Acute lower respiratory infections in developing countries. Lancet 381:1341-1342. https://doi. org/10.1016/S0140-6736(12)62178-3

2. Minor TE, Dick EC, Demeo AN, Ouellette JJ, Cohen M, Reed CE (1974) Viruses as precipitants of asthmatic attacks in children intermit ent. JAMA 227:292-298

3. Brasil. Ministério da Saude (2015) Boletim Epidemiológico Influenza: Monitoramento até a Semana Epidemiológica 52 de 2014

4. Sloots TP, Whiley DM, Lambert SB, Nissen MD (2008) Emerging respiratory agents: new viruses for old diseases ? J Clin Virol 42: 233-243. https://doi.org/10.1016/j.jcv.2008.03.002

5. Huijskens EG, Biesmans RC, Buiting AG, Obihara CC, Rossen JW (2012) Diagnostic value of respiratory virus detection in symptomatic children using real-time PCR. Virol J 9:276. https://doi.org/10. 1186/1743-422X-9-276

6. Leung TF, Chan P, Wong G, Fok T, Ng P (2013) Respiratory viruses and atypical bacteria triggering severe asthma exacerbation in children. Hong Kong Med J 19:11-14

7. Schwarze J, Openshaw P, Jha A, del Giacco S, Firinu D, Tsilochristou O, Roberts G, Selby A, Akdis C, Agache I, Custovic A, Heffler E, Pinna G, Khaitov M, Nikonova A, Papadopoulos N, Akhlaq A, Nurmatov U, Renz H, Sheikh A, Skevaki C (2018) Influenza burden, prevention, and treatment in asthma - a scoping review by the EAACI Influenza in asthma task force. Allergy 73:1151-1181. https://doi.org/10.1111/all.13333

8. Martins RB, Rocha LP, Prates MM, Gagliardi TB, Biasoli B, Leite MJ, Buzatto G, Hyppolito MA, Aragon DC, Tamashiro E, Valera FCP, Arruda E, Anselmo-lima WT (2017) Respiratory DNA viruses are undetectable in nasopharyngeal secretions from adenotonsillectomized children. PLoS One 1-7. https://doi.org/10. 1371/journal. pone. 0174188

9. Puig M, Jofre J, Lucena F, Allard A, Wadell G, Girones R (1994) Detection of adenoviruses and enteroviruses in polluted waters by nested PCR amplification. Appl Environ Microbiol 60:2963-2970

10. Coiras MT, Aguilar J, García ML, Casas I, Pérez-Brena P (2004) Simultaneous detection of fourteen respiratory viruses in clinical specimens by two multiplex reverse transcription nested-PCR assays. J Med Virol 72:484-495. https://doi.org/10.1002/jmv.20008

11. López-Huertas M, Casas I, Acosta-Herrera B, García ML, Coiras MT, Pérez-Brena P (2005) Two RT-PCR based assays to detect human metapneumovirus in nasopharyngeal aspirates. J Virol Methods 129:1-7. https://doi.org/10.1016/j.jviromet.2005.05.004

12. Pozo F, Garcia-Garcia ML, Calvo C, Cuesta I, Perez-Breña P, Casas I (2007) High incidence of human bocavirus infection in children in Spain. J Clin Virol 40:224-228. https://doi.org/10. 1016/j.jcv.2007.08.010

13. Coiras MT, Pérez-Breña P, García ML, Casas I (2003) Simultaneous detection of influenza A, B, and C viruses, respiratory syncytial virus, and adenoviruses in clinical samples by multiplex reverse transcription nested-PCR assay. J Med Virol 69:132144. https://doi.org/10.1002/jmv.10255

14. Bicer S, Giray T, Çöl D, Erdağ GÇ, Vitrinel A, Gürol Y, Çelik G, Kaspar Ç, Küçük Ö (2013) Virological and clinical characterizations of respiratory infections in hospitalized children. Ital J Pediatr 39:22. https://doi.org/10.1186/1824-7288-39-22
15. Arruda E, Jones MH, Escremim de Paula F, Chong D, Bugarin G, Notario G, Matsuno AK, Pitrez PM, Vo P, Suzuki C, Rosario Filho N, Stein RT (2014) The burden of single virus and viral coinfections on severe lower respiratory tract infections among preterm infants. Pediatr Infect Dis J 33:997-1003. https://doi.org/10. 1097/INF.0000000000000349

16. Dierig A, Heron LG, Lambert SB, Yin JK, Leask J, Chow MYK, Sloots TP, Nissen MD, Ridda I, Booy R (2014) Epidemiology of respiratory viral infections in children enrolled in a study of influenza vaccine effectiveness. Influenza Other Respir Viruses 8:293301. https://doi.org/10.1111/irv.12229

17. da Silva ER, Pitrez MCP, Arruda E, Mattiello R, Sarria EE, de Paula FE, Proença-Modena JL, Delcaro LS, Cintra O, Jones MH, Ribeiro JD, Stein RT (2013) Severe lower respiratory tract infection in infants and toddlers from a non-affluent population: viral etiology and co-detection as risk factors. BMC Infect Dis 13:41. https:// doi.org/10.1186/1471-2334-13-41

18. Bezerra PGM, Britto MCA, Correia JB, do Duarte M CMB, Fonceca AM, Rose K, Hopkins MJ, Cuevas LE, McNamara PS (2011) Viral and atypical bacterial detection in acute respiratory infection in children under five years. PLoS One 6:e18928. https://doi.org/10.1371/journal.pone.0018928

19. Albuquerque MCM, Varella RB, Santos N (2012) Acute respiratory viral infections in children in Rio de Janeiro and Teresópolis, Brazil. Rev Inst Med Trop Sao Paulo 54:249-255. https://doi.org/ 10.1590/S0036-46652012000500003

20. Ju X, Fang Q, Zhang J, Xu A, Liang L, Ke C (2014) Viral etiology of influenza-like ilnesses in Huizhou, China, from 2011 to 2013. Arch Virol 159:2003-2010. https://doi.org/10.1007/s00705-0142035-1

21. Self WH, Williams DJ, Zhu Y, Ampofo K, Pavia AT, Chappell JD, Hymas WC, Stockmann C, Bramley AM, Schneider E, Erdman D, Finelli L, Jain S, Edwards KM, Grijalva CG (2016) Respiratory viral detection in children and adults: comparing asymptomatic controls and patients with community-acquired pneumonia. J Infect Dis 213:584-591. https://doi.org/10.1093/infdis/jiv323

22. Lee S, Chiu SS, Malik PJS, Chan K, Wong HW, Lau Y (2011) Is respiratory viral infection really an important trigger of asthma exacerbations in children? Eur J Pediatr 170:1317-1324. https://doi. org/10.1007/s00431-011-1446-1

23. Jansen R, Wieringa J, Koekkoek S, Visser C, Pajkrt D, Molenkamp R, de Jong M, Schinkel J (2011) Frequent detection of respiratory viruses without symptoms: toward defining clinically relevant cutoff values. J Clin Microbiol 49:2631-2636

24. Chonmaitree T, Alvarez-fernandez P, Jennings K, Trujillo R, Marom T, Loeffelholz MJ, Miller AL, Mccormick DP, Patel JA, Pyles RB (2014) Symptomatic and asymptomatic respiratory viral infections in the first year of life: association with acute otitis media development. Clin Infect Dis 1-9. https://doi.org/10.1093/cid/ ciu714

25. Tang JW, Lai FYL, Wong F, Hon KLE (2010) Incidence of common respiratory viral infections related to climate factors in hospitalized children in Hong Kong. Epidemiol Infect 138:226-235. https://doi.org/10.1017/S0950268809990410

26. Khor C-S, Sam I-C, Hooi P-S, Quek K-F, Chan Y-F (2012) Epidemiology and seasonality of respiratory viral infections in hospitalized children in Kuala Lumpur, Malaysia: a retrospective study of 27 years. BMC Pediatr 12:1-9. https://doi.org/10.1186/14712431-12-32

27. Schlaudecker EP, Heck JP, Macintyre ET, Martinez R, Dodd CN, McNeal MM, Staat MA, Heck JE, Steinhoff MC (2012) Etiology and seasonality of viral respiratory infections in rural Honduran children. Pediatr Infect Dis J 31:1113-1118. https://doi.org/10. 1097/INF.0b013e31826052eb 
28. Moura F, Perdigão A, Siqueira MM (2009) Seasonality of influenza in the tropics: a distinct pattern in northeastern Brazil. Am J Trop Med Hyg 81:180-183

29. Gardinassi L, Marque Simas P, Salomão J, Durigon EL, Zanetta Trevisan D, Cordeiro J, Lacerda M, Rahal P, de Souz F (2012) Seasonality of viral respiratory infections in southeast of Brazil: the influence of temperature and air humidity. Braz J Microbiol 43:98-108

30. Silva DR, Viana VP, Müller AM, Livi FP, den Dalcin P TR (2014) Respiratory viral infections and effects of meteorological parameters and air pollution in adults with respiratory symptoms admitted to the emergency room. Influenza Other Respi Viruses 8:42-52. https://doi.org/10.1111/irv.12158

31. Anders KL, Nguyen HL, Nguyen NM, Van Thuy NT, Hong Van NT, Hieu NT, Hong Tham NT, Thanh Ha PT, Lien LB, Vinh Chau N, Van TY, Hang VT, van Doorn HR, Simmons CP (2015) Epidemiology and virology of acute respiratory infections during the first year of life: a birth cohort study in Vietnam. Pediatr Infect
Dis J 34:361-370. https://doi.org/10.1097/INF. 0000000000000643

32. Brasil. Ministério da Saude (2013) Boletim epidemiológico Influenza: Monitoramento até a semana epidemiológica 52 de 2013

33. De Leon C, Amantea SL, Pilger DA, Cantarelli V (2013) Clinical and epidemiological profile of lower respiratory tract infections associated with human bocavirus. Pediatr Pulmonol 48:1112-1118

34. Anh J, Choi S, Kim D, Kim K (2011) Human bocavirus isolated from children with acute respiratory tract infection in Korea, 2010 2011. J Med Virol 86:2011-2018

35. Ozcan C, Toyran M, Civelek E, Erkocoglu M, Altas AB, Albayrak N, Korukluoglu G, Kocabas CN (2011) Evaluation of respiratory viral pathogens in acute asthma exacerbations during childhood. J Asthma 48:888-893. https://doi.org/10.3109/02770903.2011. 606579

Publisher's note Springer Nature remains neutral with regard to jurisdictional claims in published maps and institutional affiliations. 